\title{
GB virus-C - a virus without a disease: We cannot give it chronic fatigue syndrome
}

\author{
James F Jones*1, Prasad S Kulkarni², Salvatore T Butera ${ }^{2}$ and \\ William C Reeves ${ }^{1}$
}

\begin{abstract}
Address: ${ }^{1}$ Viral Exanthems and Herpesvirus Branch, Division of Viral and Rickettsial Diseases, Centers for Disease Control and Prevention, 1600 Clifton Rd, mailstop A-15, Atlanta, Georgia, 30333, USA and 22Laboratory Branch, Division of HIV/AIDS Prevention, Centers for Disease Control and Prevention, 1600 Clifton Rd, mailstop G-19, Atlanta, Georgia, 30333, USA

Email: James F Jones* - jaj9@cdc.gov; Prasad S Kulkarni - pgk7@cdc.gov; Salvatore T Butera - stb3@cdc.gov; William C Reeves - wcr1@cdc.gov

* Corresponding author
\end{abstract}

Published: 28 September 2005

BMC Infectious Diseases 2005, 5:78 doi:10.1 186/147/-2334-5-78

This article is available from: http://www.biomedcentral.com/147I-2334/5/78

(C) 2005 Jones et al; licensee BioMed Central Ltd.

This is an Open Access article distributed under the terms of the Creative Commons Attribution License (http://creativecommons.org/licenses/by/2.0), which permits unrestricted use, distribution, and reproduction in any medium, provided the original work is properly cited.
Received: 28 June 2005

Accepted: 28 September 2005

\begin{abstract}
Background: Chronic fatigue syndrome (CFS) is an illness in search of an infectious etiology. GB virus-C (GBV-C) virus is a flavivirus with cell tropism and host defense induction qualities compatible with a role in producing the syndrome. The GBV-C genome is detectable in $4 \%$ of the population and $12 \%$ of the population is seropositive. The present study evaluated the association between infection with GBV and CFS.

Methods: We used a commercial EIA to detect antibodies against the GBV-C E2 protein and a quantitative real-time RT-PCR assay to detect active GBV-C infection. Sera were from a case control study of CFS in Atlanta, Georgia. The Fisher's exact two-tailed test was used for statistical analysis.

Results: Two of 12 CFS patients and one of 21 controls were seropositive for prior GBV-C infection and one control had viral RNA detected, indicating active infection. The results are not statistically different.
\end{abstract}

Conclusion: We found no evidence that active or past infection with GBV is associated with CFS.

\section{Background}

Chronic fatigue syndrome (CFS) affects 400,000 to 900,000 adults in the United States $[1,2]$. At least a quarter of those suffering from CFS are unemployed or receiving disability because of the illness; the average affected family forgoes $\$ 20,000$ annually in lost earnings and wages (approximately half of the average United States household income); and, the annual value of lost productivity in the United States is approximately \$9 billion [2-4]. Despite the public health burden imposed by CFS, diagnostic, treatment and prevention strategies have proven difficult to devise because the etiology, pathophysiology and risk factors of CFS remain unknown [reviewed in [5]].

Because the symptoms resemble those of infectious diseases and because CFS may follow an acute infectious disease, a considerable body of work has attempted to identify persistent or reactivated infection in patients with this illness [reviewed in [5]]. These efforts have included analysis of seroprevalence, evaluation of viral RNA and DNA (i.e., latent/active infection), and most recently, molecular identification procedures for unique, previ- 
ously uncharacterized pathogens [6-12]. None of these reports have developed convincing evidence for a significant association between any infectious agent and CFS.

However, negative, inconclusive, and conflicting case control studies do not mean that infectious etiologies for CFS should be dismissed. A recently discovered flavivirus, GB virus-C/HGV (GBV-C) [13-17], has many properties that demanded a study assessing its possible association with CFS. GBV-C preferentially replicates in peripheral blood mononuclear cells (PBMC), primarily $\mathrm{B}$ and $\mathrm{T}$ lymphocytes, and in bone marrow in vivo $[18,19]$. Of note, some flaviviruses activate the classic complement pathway [20] and we have found a high prevalence of split products $(\mathrm{C} 3 \mathrm{a}, \mathrm{C} 4 \mathrm{a}$, and $\mathrm{C} 5 \mathrm{a})$ in patients with $\mathrm{CFS}$ compared to controls [21]. We have also examined mononuclear cell populations for gene expression patterns and have found differences between patients and control subjects $[22,23]$. GBV-C viremia may persist for several years following primary infection and serologically antibodies are generated against the envelope protein, E2 [reviewed in $[15,18]]$. The antibodies are also long-lived and may protect against re-infection [24]. GBV-C viremia and presence of antibodies are usually mutually exclusive, and only a small percentage of exposed individuals exhibit both viremia and anti-E2 antibody [25]. As yet, no illness has been associated with GBV infection.

Therefore, thinking that complement activation and altered mononuclear cell gene expression might reflect continued infection with this virus, we chose to evaluate banked serum specimens from subjects enrolled in a case control study for GBV-C RNA, an indication of persistent active infection that might be associated with CFS and for specific antibodies associated with clearance of a GBV-C infection (anti-E2) as an indicator of past infection with this virus.

\section{Methods}

This study adhered to human experimentation guidelines of the U.S. Department of Health and Human Services and the Helsinki Declaration. The CDC Institutional Review Board approved study protocols. All participants were volunteers who gave informed consent.

\section{Study subjects}

Subjects and study design have been presented in detail elsewhere $[25,26]$. In brief, 26 patients with CFS $(23$ women and 3 men) were recruited from a physician surveillance study in Atlanta [26]. Patients met the 1988 CFS research case definition [27] and had been ill for no more than 10 years. Two age- $( \pm 5$ years $)$, race-, and sex-matched nonfatigued control subjects were contacted by means of random-digit dialing in the Atlanta area. Subjects' clinical, seroepidemiologic [6], and immunological characteristics have been reported [28]. For the current pilot study, testable sera were available from 12 cases and 21 controls.

\section{Laboratory procedures}

\section{Detection of GBV-C infection}

Plasma samples were tested for antibodies against the GBV-C E2 envelope protein by a $\mu$ PLATE Anti-HGenv microtiter assay (Roche Diagnostics Corp., Indianapolis, Ind.). Furthermore, nucleic acids were extracted from 200 $\mu \mathrm{L}$ of plasma by using the QIAamp Viral RNA Mini Kit (Qiagen Inc., Valencia, Calif.), as per the manufacturer's recommendations. A real-time quantitative reverse-transcriptase polymerase chain reaction (qRT-PCR) was developed to detect GBV-C and determine the GBV-C viral load. Five microliters of extracted nucleic acids were used in the qRT-PCR assay, performed in a final volume of 50 $\mu \mathrm{L}$ using the Quantitect Probe RT-PCR kit (Qiagen). The primers used were: GBV-C 03.1-F - 5' GCACGGTCCACAGGTGTT 3' (nucleotides 226-243 of the sequence with GenBank accession number U44402[14] and GBV-C 03.2-R - 5' GTACGTGGGCGTCGTTTG 3' (nucleotides 313-330). The probe used had the sequence $5^{\prime}$ CCGACGTCAGGCTCGTCGTTAAAC 3' (nucleotides 268291), and was labeled with 6-carboxy-fluorescein (FAM) on the $5^{\prime}$ end and a dark quencher on the $3^{\prime}$ end. This combination of primers resulted in an amplicon of 105 base pairs (bp). Serial dilutions of in vitro transcribed RNA generated from a linearized plasmid encoding nucleotides 136-400 of the 5' UTR of GBV-C with GenBank accession number $\mathrm{U} 44402[14]$ was used as a quantitative standard curve.

\section{Statistics}

Based on the estimated prevalence of GBV-C $(<4 \%)$ in healthy blood donors in the US [29], the available sample size of 12 CFS subjects and 21 controls should allow detection of $60 \%$ positivity in viremia or positive serology at the $95 \%$ confidence level with a power of 80 : with at least $50 \%$ of persons with CFS demonstrating viremia. These estimates are based on the assumption that if GBV$\mathrm{C}$ infection is the primary cause CFS, the majority of CFS subjects would be positive in one of the assay systems. Results were analyzed using Fisher's exact test (2-tailed). Odds ratios were calculated from a Chi square table and confidence intervals defined using the Wald statistic.

\section{Results and discussion}

Two cases $(16.7 \%)$ and 1 control $(4.8 \%)$ were seropositive (2-tailed Fisher's exact test $\mathrm{p}=.54$ ). Only one person (a control subject) had detectable GBV-C RNA. Although the odds ratio of this difference is 5.14 , the confidence interval (CI 0.32-49.59) demonstrates the difference was statistically insignificant. 
This exploratory study did not identify significant differences in active or cleared GBV-C infections between individuals fulfilling a clinical definition of CFS or in control subjects. These data would not exclude GBV-C infection in small percentages $(<20 \%)$ of CFS patients.

Since previous studies that used seropositivity or gene expression alone have failed to demonstrate an association between specific infections and CFS, we reasoned that a combined serological and virological approach would be more appropriate since only ongoing infection with GBV-C is associated with viremia. These results are consistent with values reported in a variety of population studies regarding the prevalence of GBV-C. Previous studies have addressed Herpesviridae, enteroviruses, retroviruses, hepatitis C, HTLV-II [5] and recently parvovirus [30] and Borna virus [31], but no definitive causative links have been made. Thus, another attempt to link a majority of CFS cases with a specific infectious agent did not identify a specific association.

\section{Conclusion}

CFS remains a clinically identifiable, but daunting, medical and psychological problem.

\section{Competing interests}

The author(s) declare that they have no competing interests

\section{Authors' contributions}

JJ and SB conceived the study. JJ was responsible for specimen identification, evaluation of results and preparation of the manuscript. PK performed the antibody and PCR procedures and participated in the preparation of the manuscript. SB supervised the laboratory procedures and participated in the preparation of the manuscript. WR was responsible for the primary patient study and participated in the design and evaluation of the study, and participated in the preparation of the manuscript.

\section{Acknowledgements}

Elizabeth R. Unger, MD, PhD contributed the title of the manuscript.

\section{References}

I. Jason LA, Richman JA, Rademaker AW, Jordan KM, Plioplys AV, Taylor RR, McCready W, Huang CF, Plioplys S: A community-based study of chronic fatigue syndrome. Arch Intern Med 1999, 159:2 I 29-37.

2. Reyes M, Nisenbaum R, Hoaglin DC, Emmons C, Stewart G, Randall B, Stewart JA, Abbey S, Jones JF, Gantz N, Minden S, Reeves WC: Prevalence and incidence of chronic fatigue syndrome in Wichita, Kansas. Arch Intern Med 2003, 163:1530-6.

3. Solomon L, Nisenbaum R, Reyes M, Papanicolaou DA, Unger ER, Reeves WC: Functional status of persons with chronic fatigue syndrome in the Wichita population. Health Qual Life Outcomes 2003, I:48

4. Reynolds KJ, Vernon SD, Bouchery E, Reeves WC: The economic impact of chronic fatigue syndrome. Cost Eff Resour Alloc 2004, 2:4.
5. Afari N, Buchwald D: Chronic fatigue syndrome: A review. Am J Psychiatry 2003, 160:221-236.

6. Mawle AC, Nisenbaum R, Dobbins JG, Gary HE Jr, Stewart JA, Reyes M, Steele L, Schmid DS, Reeves WC: Seroepidemiology of chronic fatigue syndrome: A case control study. Clin Infect Dis 1995, 2 1:1386-9.

7. Koelle DM, Barcy S, Huang ML, Ashley RL, Corey L, Zeh J, Ashton S, Buchwald $D$ : Markers of viral infection in monozygotic twins discordant for chronic fatigue syndrome. Clin Infect Dis 2002, 35:518-25.

8. Buchwald D, Ashley RL, Pearlman T, Kith P, Komaroff AL: Viral serologies in patients with chronic fatigue and chronic fatigue syndrome. J Med Virol 1996, 50:25-30.

9. Vernon SD, Shukla SK, Conradt J, Unger ER, Reeves WC: Analysis of I6S rRNA gene sequences and circulating cell-free DNA from plasma of chronic fatigue :syndrome and non-fatigued subjects. BMC Microbiol 2002, 2:39.

10. Reeves WC, Stamey FR, Black JB, Mawle AC, Stewart JA, Pellett PE: Human herpesviruses $\mathbf{6}$ and 7 in chronic fatigue syndrome: a case-control study. Clin Infect Dis 2000, 31 I:48-52.

II. Gelman JH, Unger ER, Mawle AC, Nisenbaum R, Reeves WC: Chronic fatigue syndrome is not associated with expression of endogenous retroviral pI5E. Molec Diagnosis 2000, 5:155-I56.

12. Vernon SD, Shukla S, Reeves WC: Absence of Mycoplasma species DNA in chronic fatigue syndrome. J Med Microbiol 2003 , 52: 1027-1028.

13. Simons JN, Leary TP, Dawson GJ, Pilot-Matias TJ, Muerhoff AS, Schlauder GG, Desai SM, Mushahwar IK: Isolation of novel viruslike sequences associated with human hepatitis. Nat Med 1995, I:564-9.

14. Linnen J, Wages J, Zhang-Keck Z-Y, Fry KE, Krawczynski KZ, Alter H, Koonin E, Gallagher M, Alter M, Hadziyannis S, Karayiannis P, Fung K, Nakatsuji Y, Shih JW, Young L, Piatak M Jr, Fernandez J, Chen S, Zou JC, Morris T, Hyams KC, Ismay S, Lifson JD, Hess G, Foung SK, Thomas $\mathrm{H}$, Bradley D, Margolis H, Kim JP: Molecular cloning and disease association of hepatitis $G$ virus: a transfusiontransmissible agent. Science 1996, 27 I:505-8.

15. Radkowski M, Kubicka J, Kisiel E, Cianciara J, Nowicki M, Rakela J, Laskus T: Detection of active hepatitis $\mathbf{C}$ virus and hepatitis $\mathbf{G}$ virus/GB virus $C$ replication in bone marrow in human subjects. Blood 2000, 95:3986-9.

16. Zuckerman AJ: Alphabet of hepatitis viruses. Lancet 1996, 347:558-9.

17. Leary TP, Muerhoff AS, Simons JN, Pilot-Matias TJ, Erker JC, Chalmers ML, Schlauder GG, Dawson G], Desai SM: Sequence and genomic organization of GBV-C: a novel member of the flaviviridae associated with human non-A-E hepatitis. J Med Virol 1996, 48:60-7.

18. Stapleton JT, Williams CF, Xiang J: GB Virus Type C: a beneficial infection? / Clin Microbiol 2004, 42:3915-9.

19. Zampino R, Pickering J, labal M, Gaud U, Thomas HC, Karayiannis P: Hepatitis $G$ virus/GBV-C persistence: absence of hypervariable E2 region and genetic analysis of viral quasispecies in serum and lymphocytes. J Viral Hepatitis 1999, 6:209-18.

20. Diamond MS, Shrestha B, Mehlhop E, Sitati E, Engle M: Innate and adaptive immune responses determine protection against disseminated infection by West Nile encephalitis virus. Viral Immunol 2003:259-78.

21. Sorensen B, Streib JE, Strand M, Make B, Giclas PC, Fleshner M, Jones $\mathrm{J}$ : Complement activation in a model of chronic fatigue syndrome. J Allergy Clin Immunol 2003, I I 2:397-403.

22. Steinau M, Unger ER, Jones JF, Rajeevan MS: Differential display PCR of peripheral blood for biomarker discovery in chronic fatigue syndrome. J Mol Med 2004, 82:750-5.

23. Whistler T, Unger ER, Nisenbaum R, Vernon SD: Integration of gene expression, clinical, and epidemiologic data to characterize Chronic Fatigue Syndrome. I Transl Med 2003, I: 10.

24. Thomas DL, Vlahov D, Alter HJ, Hunt JC, Marshall R, Astemborski J, Nelson KE: Association of antibody to $\mathbf{G B}$ virus $\mathbf{C}$ (hepatitis $\mathbf{G}$ virus) with viral clearance and protection from reinfection. Infect Dis 1998, 177:539-42.

25. Gutierrez RA, Dawson G], Knigge MF, Melvin SL, Heynen CA, Kyrk CR, Young CE, Carrick RJ, Schlauder GG, Surowy TK, Dille BJ, Coleman PF, Thiele DL, Lentino JR, Pachucki C, Mushahwar IK: Seroprevalence of GB virus $C$ and persistence of RNA and antibody. J Med Viro 1997, 53:167-73. 
26. Reyes M, Gary HE Jr, Dobbins JG, Randall B, Steele L, Fukuda K, Holmes GP, Connell DG, Mawle AC, Schmid DS, Stewart JA, Schonberger LB, Gunn WJ, Reeves WC: Surveillance for chronic fatigue syndrome-four U.S. cities, September 1989 through August 1993. MMWR CDC Surveill Summ 1997, 46:I-I3.

27. Holmes GP, Kaplan JE, Gantz NM, Komaroff AL, Schonberger LB, Straus SE, Jones JF, Dubois RE, Cunningham-Rundles C, Pahwa S, Tosato G, Zegans LS, Purtilo DT, Brown N, Schooley RT, Brus R: Chronic fatigue syndrome: a working case definition. Ann Intern Med 1988, 108:387-9.

28. Mawle AC, Nisenbaum R, Dobbins JG, Gary HE Jr, Stewart JA, Reyes M, Steele L, Schmid DS, Reeves WC: Immune responses associated with chronic fatigue syndrome: a case-control study. J Infect Dis 1997, 175:136-41.

29. Simons JN, Desai SM, Mushahwar IK: The GB viruses. Curr Top Microbiol Immunol 2000, 242:34I-75.

30. Kerr JR, Bracewell J, Laing I, Mattey DL, Bernstein RM, Bruce IN, Tyrrell DA: Chronic fatigue syndrome and arthralgia following parvovirus B I 9 infection. J Rheumatol 2002, 29:595-602.

31. Li YJ, Wang DX, Zhang FM, Liu ZD, Yang AY, Ykuta K: Detection of antibody against Borna disease virus-p24 in the plasma of Chinese patients with chronic fatigue syndrome by Westernblot analysis. Zhonghua Shi Yan He Lin Chuang Bing Du Xue Za Zhi 2003, 17:330-3.

\section{Pre-publication history}

The pre-publication history for this paper can be accessed here:

http://www.biomedcentral.com/1471-2334/5/78/prepub

Publish with Biomed Central and every scientist can read your work free of charge

"BioMed Central will be the most significant development for disseminating the results of biomedical research in our lifetime. "

Sir Paul Nurse, Cancer Research UK

Your research papers will be:

- available free of charge to the entire biomedical community

- peer reviewed and published immediately upon acceptance

- cited in PubMed and archived on PubMed Central

- yours - you keep the copyright

Submit your manuscript here:

http://www.biomedcentral.com/info/publishing_adv.asp 